\title{
Chapter 14 \\ Mediation and Conciliation in Collective \\ Labor Conflicts in the United Kingdom
}

\author{
Kristina Potočnik, Sara Chaudhry and Marta Bernal-Valencia
}

The Case

Employment Relations in Scottish Refinery-Background

In 2008, 1200 workers at one of the Scottish oil refineries held a 48-h strike. Employees, members of a large trade union, were seeking to protect their existing pension scheme. The company's majority shareholder came to terms with the trade union. In October 2013, he halted production (initially as a safety measure preceding strike action) and additionally initiated a lockout even after strike action had been called off. Furthermore, he bypassed the union by offering individual employees deals capitalizing on their fear of losing their jobs.

Position of Parties Involved-A Historical Overview

Two key disputes, involving the same stakeholders, emerged in this specific organizational context. In 2008, the trade union claimed that the company had already reduced its contributions to the pension scheme by introducing financial penalties for early retirement. The existence of a non-contributory pension scheme was due to the lower salaries-employees made $£ 6000$ a year less than workers in other refineries did. The changes proposed by the company would have further reduced members' payouts by an average $£ 10,000$ a year. In 2013 , the union was caught off guard during a dispute involving a former union organizer. A third of the union members individually agreed to terms that included no strikes for three years, no further full-time union conveners, a one-time $£ 15,000$ payout and an enhanced employer contribution to the pension scheme in return for acceptance of worsening terms and conditions of employment in the coming years.

K. Potočnik $(\varangle) \cdot S$. Chaudhry $\cdot$ M. Bernal-Valencia

University of Edinburgh Business School, 29 Buccleuch Place, EH 9JS Edinburgh, UK

e-mail: kristina.potocnik@ed.ac.uk

(C) The Author(s) 2019

M. Euwema et al. (eds.), Mediation in Collective Labor Conflicts, Industrial Relations

\& Conflict Management, https://doi.org/10.1007/978-3-319-92531-8_14 


\section{Third Party Intervention in the Dispute}

Acas was acting as a third party in the conciliation process for both disputes. Conciliation talks held at Acas offices over two days in 2008 prior to the strike taking place, involved discussion of issues of safety and integrity of the refinery site. However, the parties did not come to an agreement with respect to the underlying issue of the dispute-i.e., reduced employer contributions to the pension scheme and the strike took place four days after these talks Acas proactively offered assistance to both parties in pursuing an agreement. Eventually, the agreement was reached. Conversely, in 2013 the trade union formally asked the employer to involve Acas in the dispute resolution process. Despite their initial reluctance to do so, they were eventually persuaded to attend the talks at Acas. However, the employer attended these talks with no intention to resolve the conflict and in fact they walked out of these negotiations and also denied elected union representatives time-off to meet Westminster government ministers in London. Furthermore, the employer initiated a lockout, threatened permanent plant closure and capitalized on a trade union representative's suspension (based on an independent political scandal) to defeat trade union's organized action in the workplace.

In both disputes, Acas was involved prior to the strike and lockout taking place. In 2008, Acas helped parties reach an agreement on issues of safety and integrity, although the key issue underlying the collective conflict was not solved. In 2013, Acas did their best to help both parties reach an agreement but the conciliation talks fail ed because one of the parties was alleged to have entered the talks without any intention to solve the conflict.

The Scottish refinery case was derived from the following sources: Lyon (2017), Arrowsmith (2008), Balakrishnan (2008), BBC (2013, 2014), McAlpine (2013), Peev and Allen (2013) and Seymour (2013). We can contrast this case with our own recent experience of the UCU-UUK pensions dispute. The first and second authors of this chapter took part in the industrial action to defend a guaranteed pension. The industrial action started before Acas was involved. In this case the union was more proactive (compared to the UUK) in trying to use collective conciliation to solve the conflict. With the help of Acas, the UCU and UUK eventually reached an interim agreement and therefore a further round of industrial action that had been provisionally announced was instead cancelled.

\subsection{Introduction}

According to Acas, a state-founded mediation body with a mission to facilitate the resolution of employment conflicts in Great Britain, an organizational or workplace conflict is defined as 'discontent arising from a perceived clash of interests and may 
be collective or individual, involving action such as a strike, raising a grievance or taking disciplinary measures' (Dix, Forth, \& Sisson, 2008). According to Podro and Suff (2009), collective conciliation to settle such organizational conflicts has been a characteristic of British industrial relations for more than a century. Other forms of collective conflict management are collective mediation and arbitration, however our findings highlighted that collective conciliation is the dominant form of collective dispute resolution and the other two mechanisms are comparatively less used in the UK. For instance, our primary data collection from practitioners highlighted that mediation is seen by key stakeholders (i.e. organizations and trade unions) as a 'halfway house' and hence not a preferred option.

The overall pattern of organizational conflicts in the UK has changed over recent years showing a decline in collective disputes (see Fig. 14.1 for the number of stoppages and Fig. 14.2 for the number of working days lost, respectively). Our primary data suggests that Acas deals with 850 collective disputes on an annual basis in recent years. This relatively low number compared to previous years is not surprising since trade unions in the UK have been losing power since Margaret Thatcher came into power in 1979. Interestingly, the post-Thatcher governments have also been initiating legislative amendments that restrict the activities of trade unions in the UK. Several laws have been enacted to this end, such as allowing a union to be sued, introducing specific balloting rules prior to strike action (reducing balloting because of threshold requirements), and proscribing secondary and unofficial actions, all considered as making it more difficult to strike (Dix, Forth, \& Sisson, 2008). For instance, the New Labour's first white paper on Fairness at Work also sought to weaken the trade unions (Dix et al., 2008). ${ }^{1}$ Apart from these state-initiated changes other factors have also affected employment relations, including the cyclical pattern of economic activity, changes in the distribution of employment, weakened trade unions in terms of density and bargaining coverage, an increase in HR professionalism, trade liberalization and globalization (Dix et al., 2008; Dix \& Barber, 2015). Comparing disputes among different industries, Heery and Nash (2011) reported that health, local government, education, manufacturing and central government to be the most dispute-prone sectors.

Furthermore, the number and strength of works councils, commonly referred to as joint consultative committees (JCC's) in Great Britain, has also been steadily declining; though at a slower rate (Adam, Purcell, \& Hall, 2014). The most dramatic JCC declines were experienced in the finance, wholesale, retail, hotel and restaurant industries (Van Wanrooy, Bewley, Bryson, Forth, Freeth, Stokes, \& Wood, 2013). More importantly, JCC's are criticized for not engaging in any meaningful consultation with employees. Instead, they are described as "communicators of decisions that had already been taken by management, rather than as bodies engaged in active consultation' (Hall, Hutchinson, Purcell, Terry, \& Parker, 2011) and even the ICE Regulations $^{2}$ have not enhanced the practice of active, joint consultation via works

\footnotetext{
${ }^{1}$ The level of unionisation has fallen from 12.6 million registered members in 1980 to 6.9 million in 2016 (Certification Officer, 2016).

${ }^{2}$ Information and Consultation of Employees Regulations-introduced in the UK in 2005.
} 


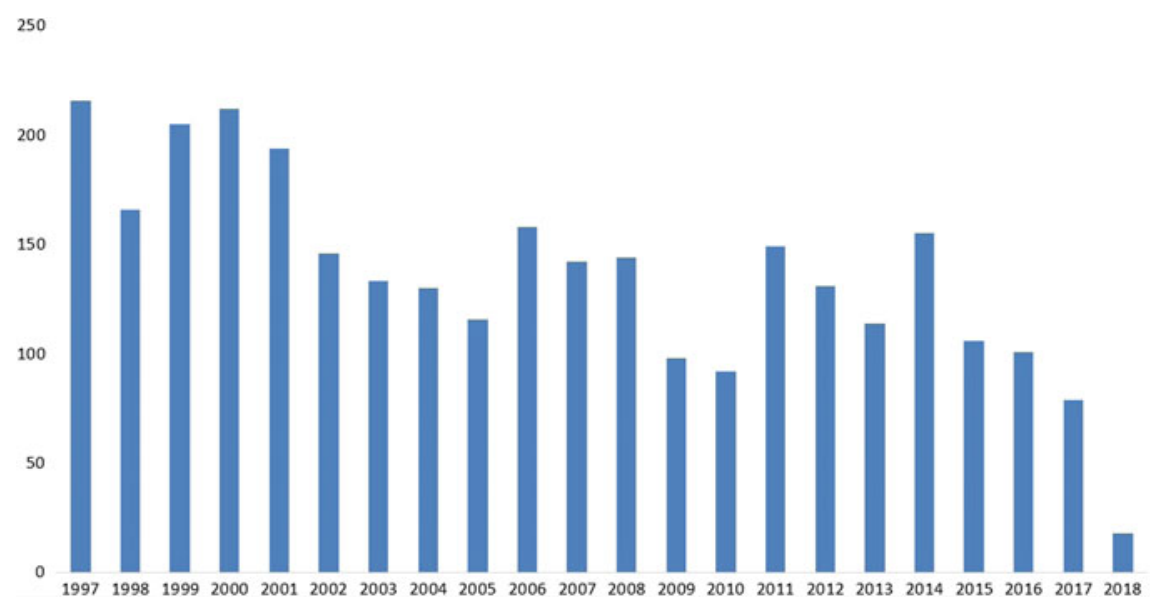

Fig. 14.1 Number of workplace stoppages per year in the UK (since 1997). Based on ONS (2018). The data for 2018 is up to the end of January

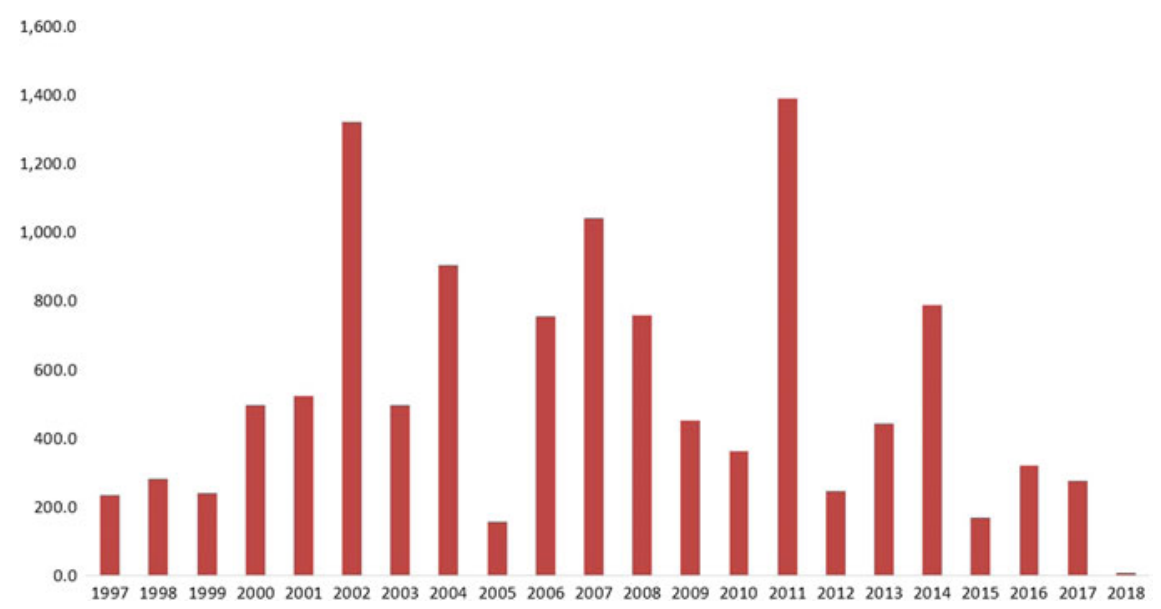

Fig. 14.2 Number of working days lost (in thousands) in the UK (since 1997). Based on ONS (2018). The data for 2018 is up to the end of January

councils (Van Wanrooy et al., 2013). Therefore, works councils/JCCs are unlikely to participate in collective dispute processes because of a significant narrowing of their agenda and role, in contrast to the important role played by works councils in other European countries like Germany, Sweden, and the Netherlands, amongst others.

Unsurprisingly, against this employment relations backdrop, statistics for official strikes show very low averages when compared with historical data (see Fig. 14.1) whereas individual employment claims to Employment Tribunals (ETs) have increased (apart from a minor decrease_-see below). 
This pattern of an increasingly individualized employment relationship may indicate on the one hand an 'individualization phenomenon' (Dix et al., 2008) whilst on the other hand, it reflects unions' decline of power and their new strategy to enforce and protect existing rights established by legislation (Dix et al., 2008). Nevertheless, the recent growth in multiple ET cases involving a single issue (or a set of issues) affecting a number of people in the same workplace or organization suggests the continuing importance of collective issues (Dix \& Barber, 2015). The rise of multiple ET cases is heavily influenced by large scale disputes, primarily as a union-led tactic to change or maintain control in negotiations. There was a short-term decline in ET claims by individuals when tribunal fees were introduced in 2013 (Dix \& Barber, 2015). However, these fees were abolished in July 2017 given a Supreme Court ruling (Renaudon, 2017) and in the proceeding month's tribunal claims for individual cases showed a $100 \%$ increase.

In this chapter, we discuss the collective conciliation and mediation practices in the UK. It is worth pointing out that the same employment law applies to private and public sectors in the UK and hence the same collective conciliation and mediation system is used in both sectors.

\subsection{Characteristics of the System}

The existing mediation model in the UK was decided in 2002, when new employment legislation was enacted (principally the Employment Act of 2002 and Dispute Resolution Regulations of 2004). Against the theoretical backdrop of the 3R model of workplace mediation (Bollen, Euwema, \& Munduate, 2016), the British dispute resolution system can be characterized as a predominantly voluntarist approach to collective conciliation and mediation (Latreille, 2011; Saundry, Bennett, \& Wibberley, 2013). The employment law in the UK does not impose either conciliation or mediation on disputing parties and the trade union can call for strike action if its members support it without going through collective conciliation or mediation first. If disputing parties do decide to take advantage of third party dispute resolution the most frequent port of call would be Acas. This is state-supported organization almost entirely funded by the government and acts impartially in providing a range of best practices and dispute resolution services (Dix \& Oxenbridge, 2004). The Labour Relations Agency (LRA) is the equivalent body in Northern Ireland. Specifically, the Trade Union and Labour Relations (Consolidation) Act TULRCA 1992s 210 establishes the following: "where a trade dispute exists or is apprehended Acas may, at the request of one or more parties to the dispute or otherwise, offer the parties to the dispute its assistance with a view to bringing about a settlement". Therefore, Acas may be part of the mediation process depending on the will of the parties involved and Acas involvement is not compulsory in collective disputes (Podro \& Suff, 2009). Any of the disputing parties can request help from Acas or they can also jointly approach Acas in seeking help to resolve the dispute (Bond, 2011). In Acas' 2016 collective conciliation evaluation survey $89 \%$ of the total surveyed participants reported that 
their organizations had a formal procedure for dealing with collective conflicts in place. Of this, $69 \%$ indicated that in case of failure to agree, their formal procedure included a referral to Acas (Booth, Clemence, \& Gariban, 2016).

Acas distinguishes between collective conciliation, mediation and arbitration mechanisms. Collective conciliation is defined as "talks aimed at resolving disputes between representative groups (most typically trade unions) and employers-facilitated by an independent third party" (Podro \& Suff, 2009) and Acas emphasizes that the parties themselves decide the outcome and it primarily helps them find common ground and move forward. Collective mediation according to Acas refers to "making recommendations to attempt to resolve the dispute" (Podro \& Suff, 2009) which parties have to consider. Collective mediation is pursued if collective conciliation has not been successful and the parties are still committed to settle the conflict without the use of coercive action (i.e., work stoppages, strikes or lockouts). Our primary data highlights that issues that escalate to collective mediation include procedural deficiencies, misuse of the law, dismissal of trade unions representatives etc. In terms of role expectations of conflicting parties (Bollen et al., 2016), they will agree on the terms of reference before mediation begins. The role of Acas is focused on offering recommendations aimed at settling the dispute, and parties are encouraged to accept these recommendations. Finally, Acas defines collective arbitration as a process whereby the parties are given a written decision, which they accepted to implement in advance, and the dispute formally concludes when both parties agree on the final terms of reference.

In terms of relations between the disputing parties and a neutral third party (Bollen et al., 2016) like Acas-it is considered that conciliation and mediation are appropriate means of collective conflict resolution only after the involved parties have exhausted all possibilities of solving the conflict by themselves or if the circumstances are so adverse that the parties agree they are in need of assistance from a third party to solve their conflict. Externally-provided alternative dispute resolution, such as by Acas, is expected to help solve most disputes, although it might not be suitable in all cases (Gibbons, 2007). For instance, large organizations usually rely on extensive internal dispute resolution procedures involving internal or bought-in mediation expertise. This approach to dispute resolution by larger organizations is primarily relevant because in heavily unionized workplaces, conflict is likely to occur and be resolved via direct negotiation with unions. Furthermore, our interview with Acas' chief conciliator revealed that organizations often deal with disputes internally because they '.... are relationship-based rather than terms and conditions of employment...' Therefore, they would be very unlikely to resolve conflicts by immediately resorting to Acas procedures because trade unions use balloting process or ballot results as a key negotiation tactic to threaten action. This increases their bargaining power without actually initiating action (Van Wanrooy et al., 2013). This negotiation advantage would be lost if third parties like Acas were involved at the outset because both organizational and trade union policy prohibits industrial action if a dispute is to be referred to an outside body for collective conciliation or mediation (Bond, 2011; Molloy, Legard, \& Lewis, 2003; Van Wanrooy et al., 2013). For instance, users of the Acas services reported relying on bargaining processes $(81 \%)$ and escalating 
disputes to more senior personnel members $(68 \%)$ prior to Acas involvement. In fact, in more recent times an increase was reported in the use of the threat of industrial action (an increase to $42 \%$ in 2016 from 26\% in 2012) before ACAS was involved in the dispute resolution process (Booth et al., 2016).

Nevertheless, the latest WERS (Workplace Employment Relations Study) data highlights that the proportion of workplaces with internal collective dispute procedures fell from $40 \%$ in 2004 to $35 \%$ in 2011 and only two-thirds (66\%) of workplaces with a collective dispute procedure actually used it (Van Wanrooy et al., 2013) - this is attributed primarily to falling unionization levels. Two thirds of organizations $(68 \%)$ have provisions for referral to external bodies in their internal collective dispute policies (ibid) and Acas remains the most popular external body referred to in collective disputes (in comparison to independent mediators, employer associations etc.). Furthermore, the most common use of Acas in collective dispute resolution is for conciliation (37\%) followed by arbitration (25\%) - while only $9 \%$ of the referrals were for collective mediation (ibid). In 2014-15 there were 1371 cases of collective conciliation but only 19 arbitrations (Corby, 2015).

Apart from Acas, the disputing parties can turn to a wide range of other organizations, including advisory bodies such as Citizens Advice Bureau and members of the Civil Mediation Council. There are also private organizations ranging from lawyers and consultants, to dedicated ADR and mediation organizations such as the ADR Group, CEDR (Centre for Effective Dispute Resolution) and Mediation UK (Podro $\&$ Suff, 2005). Practitioners in our sample noted that lack of negotiation experience of key stakeholders in the dispute places the onus of explaining the basics of the process on third party conciliators.

In terms of public vs private sector organizations, Acas research suggests that the public sector has involved ACAS in their dispute resolution to a lesser extent than the private sector (Dawe \& Neathey, 2008; Podro \& Suff, 2009; Ruhemann, 2010). The less frequent use of collective conciliation and mediation by public service organizations is puzzling given that up to $83 \%$ of the public sector workplaces have collective bargaining compared to only around $14 \%$ in the private sector (Podro \& Suff, 2009). With over two-thirds of industrial actions, the public sector is also considerably more strike prone than the private sector (Heery \& Nash, 2011). Nevertheless, Acas has provided their conciliation services in the railways, London Underground, colleges and universities, the NHS and fire brigade, to name a few examples. Overall, lower involvement of Acas in public sector collective disputes can be attributed to the fact that conciliation may sometimes be seen as a willingness to compromise by typically strong public sector unions. Unsurprisingly, the recent 2016 evaluation survey highlighted that the majority of organizations using collective conciliation are from the private sector $(65 \%)$, whereas organizations from public sector comprised a total of $26 \%$ of disputes and voluntary/not-for-profit organizations accounted for $9 \%$ of disputes (Booth et al., 2016).

Acas involvement varies across individual versus collective disputes. Acas provides free conciliation for both collective and individual disputes (the latter is free only in relation to alleged infringement of employment rights) (Corby, 2015). In contrast, Acas provision of mediation for individual conflicts is for a fee. Acas can also 
offer mediation for collective disputes and this service is provided by an independent panel of mediators.

In terms of the extent of the use of the conflict resolution system in the UK, employers are increasingly choosing conciliation to resolve workplace conflict. Dix and Oxenbridge (2004) have summarized the volume of collective conciliation requests in the 1974-2003 period. They observed a peak in conciliation requests between 1976 and 1978 at more than 3000. The request for collective conciliation fell substantially in the 1980s, most likely due to sectoral and legislation changes to union powers. However, despite this the demand for collective conciliation remained steady between 1990 and 2002 at approximately 1300 requests. The most recent data shows that the demand for collective conciliation slightly decreased to 1054 requests in 2010/2011, but it increased again to 1372 requests in 2014/2015 (Booth et al., 2016). Most frequently, these recent disputes were about pay (an issue on $46 \%$ of disputes), followed by other terms of employment, such as pensions, annual leave, etc. (26\% of disputes), recognition of a trade union (18\%), changes in working practices ( $9 \%)$, and redundancy $(5 \%)$. In terms of the parties involved, the recent survey about the conciliation of collective disputes reports only cases that involve employers (management) and trade union representatives (Booth et al., 2016).

\section{Evaluation of Stakeholders on the System}

An attitudinal study on trade union officers highlighted that trade union officials were somewhat ambivalent about the differences between collective mediation and conciliation (Bond, 2011). This suggests a lack of awareness of how these respective Acas services are distinctive from a stakeholder perspective, a point we also observed in our primary data. More importantly, the current system was evaluated as effective because it not only has the potential to bring the parties back to the negotiating table but additionally the use of a neutral third party can help better manage the emotional undercurrents of the dispute. Trade union officials suggested that they would turn to the third party for help either when they wanted to make their position stronger or when they felt their position was weak with respect to the employers. In these circumstances they would turn to third parties so as to put more pressure on management to move towards their proposed solution.

Interestingly, all our participants, including trade union representatives, strongly agreed that the voluntarist approach to dispute resolution in the UK worked given the overall industrial relations climate. Finally, our primary data also suggests that due to the recent Trade Union Act of 2016 trade unions were engaging in more consultative balloting (due to increased ballot threshold requirements) and therefore approaching ACAS at earlier stages of collective disputes as compared to the past. 


\subsection{Characteristics of the Mediators or Facilitators and the Third Party Procedures}

The collective conciliation and mediation processes will be characterized by the particular style of conciliation and mediation involved. There are different models of conciliation and mediation, mainly based on facilitative, evaluative, transformative, transactional and directive approaches (Acas, 2013). Facilitative mediation, operationalized in almost identical terms as conciliation, is the process in which the mediator is in charge of the process, asks questions but does not give advice or provide solutions, and it is the most common approach among the UK-based mediators (Saundry et al., 2013). The mediators we interviewed follow the Scottish Mediation Code of Practice, which does not dictate a form of mediation, though they suggested the facilitative approach as the most common approach in most workplaces. However, our participants also highlighted that in reality most mediators tend to draw on a range of approaches during different stages of the dispute resolution process in order to facilitate a resolution.

The users of Acas collective conciliation function have also identified different conciliation styles, ranging from the "go-between" to "proactive" style. The "gobetween" conciliators were characterized as those who were mainly conveying messages but did not explain the underlying factors that influenced each party's position. In contrast, the "proactive" conciliators were perceived to not only be conveying the messages but also using tactics to make the involved parties think of solutions by presenting options or pointing towards areas of agreement in order to facilitate a settlement (Dix \& Oxenbridge, 2004; Molloy et al., 2003). Needless to say, the vast majority of parties preferred the proactive conciliation style. There is also evidence that some conciliators tend to adapt their style to different people or stages of the conciliation process, which was classified as an "adaptive" conciliation style (ibid). We discuss about how the conciliation and mediation work in more detail later on in this chapter.

Collective conciliators are led by the chief conciliator and are based in offices across England, Wales, and Scotland. They help parties settle conflicts in both local and national disputes (Podro \& Suff, 2009). There are several organizations that are positioning themselves as the register for mediators. Our specialist mediator interviewees, who were all working independent from Acas, were registered with Scottish Mediation, but across the UK there is also CEDR, UK Mediation and others, though CEDR is likely the biggest and best established. Importantly, all these organizations deal with all forms of mediation, and a large proportion of individuals who are registered with them do not actually practice or do so rarely. Therefore, it is difficult to establish how many mediators there are in the UK.

In terms of collective conciliation in particular, the conciliators have on average of eight years of experience, with almost one third having more than 10 years of experience as of March 2007. Approximately one in ten work exclusively on collective conciliation. Podro and Suff (2009) report that conciliator behaviors and techniques used are more important in determining the success of conciliation than 
the characteristics of the dispute at hand (e.g., a threat of strike, type of conflict etc.). Particularly effective behaviors for successful collective conciliation outcomes are proactivity in seeking agreement (e.g., making a judgement about what is appropriate in a given situation), availability when needed outside the meeting and beyond established working hours, the establishment of conciliation rules and boundaries, and trustworthiness (Booth et al., 2016; Dix \& Oxenbridge, 2004; Podro \& Suff, 2009).

Another important characteristic of mediators and conciliators is the one of independence and impartiality conceptualized in terms of conciliators showing they did not have a vested interest in the terms of the agreement and clarifying they were not negotiating on behalf of any of the parties involved (Bond, 2011; Dix \& Oxenbridge, 2004; Molloy et al., 2003). Both mediators and policy makers from our sample highlighted very strongly the importance of impartiality and how this is the key determining characteristic of the success of collective conciliation and mediation in the UK.

Our primary data also highlighted that the impartiality of mediators was guaranteed further by the fact that the mediators are not specifically affiliated to any trade union or employer which our participants saw as being fundamental to their role.

There is no formal/state regulation of the mediation profession at present and individuals can practice as mediators without any specific training. However, this might change in the future since organizations such as CEDR and Scottish Mediation are working to change these practices. Organizations with internal mediation schemes most frequently resort to their HR team for internal mediation who are formally trained by external providers, oftentimes by Acas (Latrielle, 2011). Our findings highlighted that Acas provides comprehensive training to its own conciliation staff, and on occasion also offers advice and support to other countries' conciliation services.

Independent mediators whom we interviewed suggested that when they were asked to mediate in a workplace, they were usually paid by the employer. Charges for Acas' services, with respect to both collective conciliation and mediation, was addressed in the earlier section (see the 'Characteristics of the system').

\section{Evaluation by Stakeholders of the Facilitators/Mediators and Third Party Procedures}

A key finding of this project was the degree of trust placed in the competence of Acas as a viable and reliable third party for dispute resolution purposes. Second, our trade union participants highlighted that long-standing relationships with local mediators and regional Acas offices facilitated trust during conflict resolution processes. In fact, Acas sees this as part of their stakeholder engagement policy-i.e. 'maintaining contact with the trade union representatives... and also the companies' human resource directors...' (Interview with Acas' chief conciliator). These relationships were further facilitated by organizations and unions involving Acas in setting up recognition agreements as well as involving Acas in analyzing the overall employment relations climate in the organization through a 'diagnostics workshop' that also helped highlight any ancillary issues that might have cropped up during the conciliation process (ibid). Interestingly both management and trade union officials felt that Acas 
representatives were 'on their side' despite Acas openly and 'jealously guard(ing) (their) impartiality... because if we bias towards one side or the other our value goes out of the window' (Interview with Acas' chief conciliator). This suggests an open and trusting relationship (above and beyond specific trade disputes) that facilitates conversations between Acas representatives and respective managerial and union reps. All our mediator participants came across as very passionate, enthusiastic and socially integrated in the local employment relations context.

\subsection{Description of the Facilitation and/or Mediation Process}

Given the voluntarist arrangements predominant in the UK, Acas has no power to force parties to cooperate or impose a solution for disputes. Our interview with Acas' chief conciliator highlighted that disputing parties 'bring in Acas on a voluntary basis... we encourage the parties to exhaust their internal procedures on disputes before getting us involved...'. Therefore, the collective conciliation process usually starts with the "failure to agree" at the end of internal bargaining suggesting an ongoing conflictual relationship between both parties. The recent collective conciliation survey suggests that in $31 \%$ of the surveyed cases, Acas got involved after the parties had negotiated for 1-3 months and in 28\% of the cases from 4-6 months. Only in $8 \%$ of the cases had Acas became involved after the parties had negotiated on their own for more than a year (Booth et al., 2016). Most frequently, Acas is likely to get involved after the disputing parties have made several attempts to solve a dispute, followed by situations in which the parties have stopped communicating or have reached a deadlock or a complete impasse (Booth et al., 2016; Ruhemann, 2010). Importantly, the majority of conciliation users on both sides of the collective dispute felt that involving Acas earlier in their negotiation process would not have been beneficial to reaching an eventual agreement because they felt it was important to utilize their mutually agreed conflict resolution procedures first. This once again underscores the importance, and stakeholder buy-in, of voluntarist arrangements in the UK.

Conciliation talks may take place on neutral territory such as Acas offices and involve different types of meetings (as explained below). According to Dix and Oxenbridge (2004), the only mandatory requirement imposed on both parties in the collective conciliation process is that they are willing to talk to each other. These authors found that the conciliation process is most frequently initiated jointly by both management and trade union (47\%), by trade union alone $(28 \%)$, by employer alone (14\%), and by Acas (11\%). An overall impression of both parties seems to be that showing willingness to use conciliation conveys a positive message to the other party (Molloy et al., 2003). Our participants also highlighted that the success of the collective conciliation process depended on disputing parties' willingness to engage in third party dispute resolution in the first place. 
A typical conciliation meeting will start with a pre-conciliation stage in which the conciliator's terms of reference are agreed by all disputing parties beforehand to ensure everyone has clear expectations of what the conciliator is asked to do. The conciliator will then meet each party in a separate meeting to hear both sides of the story, to establish what the factors underpinning the dispute are, and find out what each party hopes to achieve from the conciliation process. A joint meeting (or a series of joint meetings) with all disputing parties will follow in which the conciliator will ask the parties to share their evidence with each other without interruptions in order to explore possible solutions to the dispute (Saundry et al., 2013). At the end of this meeting, the conciliator will also summarize and record in writing the main areas of agreement and disagreement in order to plan the next stages of the conciliation process.

Based on the collected information, the conciliator will start encouraging communication between the parties, shifting the focus from the past to the future and looking for constructive solutions. The conciliator will encourage joint problem-solving by the parties and building and writing an agreement. Upon reaching an agreement, the conciliator will bring a copy of the agreed statement that both parties will need to sign. In case of no agreement, anything that has been said during the conciliation cannot be used in future proceedings (Acas, 2013). In the case of no resolution our participants also highlighted that all material revealed during the collective conciliation process is confidential. If the conflict cannot be solved through either collective conciliation or mediation, the disputing parties can opt for collective arbitration, which will lead to an outcome both parties must, in most cases, adhere to. This last option is very rarely utilized in the UK and our participants confirmed that collective arbitration implied a complete loss of negotiation power and signaled conceding their position in the dispute. Interestingly, they also highlighted that collective arbitration undercuts the potential of building long-standing, trust-based relationships between management and trade unions.

Another option is the cooling down period whereby the parties would go back to their constituent members for consultation and work on any future plan of action. For the trade union representatives, this might include a possibility of strike or industrial action.

In the case of collective arbitration, the collective conciliator draws up the key terms of reference. The next stage involves the appointment of the arbitrator by Acas from a panel of outside experts, so that Acas can preserve its neutrality and not become involved in actual adjudication. The arbitrator then consults all relevant documents regarding the case after which a hearing is held for all parties to present the key points of their case as well as answering any questions raised by the opposing party. After questioning from the arbitrator, the parties present their closing statements. The arbitrator then deliberates on the evidence and statements presented and sends a written award statement to the Acas, that after due scrutiny is forwarded to the concerned parties (Corby, 2015). 


\section{Evaluation by Stakeholders of the Mediators and Mediation Process}

Our findings suggest that the trade union representatives are happy with how the current mediation process allows them flexibility and stakeholder autonomy. Trade union participants as well as professional mediators in our focus group, despite coming from different parts of Scotland, already knew each other and stressed how these longstanding, informal relationships facilitated formal dispute resolution process. Our findings suggested that trade unions are more knowledgeable in regards to collective conflict resolution than the employers are, mainly because trade unions are organized and train their representatives when they recognize a knowledge gap to deal with the conflict resolution appropriately, whereas the employers are not. It was further added that many times HR advisors in charge of managing the employers' role in a trade dispute resolution process would not have any experience of dispute resolution or had not had to deal with one in years. Therefore, it was argued that conciliators find it easier to deal with trade union representatives than the employers' representatives. It was overall suggested that 'organized workplaces (i.e., unionized) are much more effective than unorganized workplaces'. In relation to the process, one trade union representative suggested that there is 'a misconception... a longheld sort of myth that the trade unions are out there somehow to wreck industry... nothing could be further from the truth... if the industries are wrecked, then it is our members who are losing their jobs... what is our biggest role is trying to stop management self-destroying their own industries to a certain degree'. In the discussion, this was interpreted as trade unions having a positive overall attitude towards using collective conciliation as means to help resolve a collective conflict in the workplace. As mentioned above, in case of no agreement as a result of conciliation process, the collective arbitration was not the preferred route to resolving disputes in largely voluntarist industrial relations context.

\subsection{Effectiveness of the System}

The ACAS survey data suggests that the overall satisfaction with the Acas' conciliation service has been high over time, both from the management and employee representatives' points of view (Booth et al., 2016; Dawe \& Neathey, 2008; Dix \& Oxenbridge, 2004; Molloy et al., 2003). According to the recent collective conciliation survey, a total of $76 \%$ of Acas users reported a successful outcome compared to $81 \%$ as reported in 2012. Across the smaller sub-set of users who did not report a resolution of their dispute, $91 \%$ of them acknowledged that their appointed conciliator could not have done more to bring about a successful settlement (Booth et al, 2016). A total of $91 \%$ of agreements reached during the conciliation were implemented fully and in $76 \%$ of successful cases it was perceived that the implemented agreement resolved the conflict. Our primary findings also suggest that the trade union representatives, mediators and policy makers all agree that the current system is effective and importantly, should remain voluntary. 
When the users of collective conciliation were surveyed about their experience in 2007 , a total of $89 \%$ of employee representatives and $82 \%$ of managers were satisfied with the collective conciliation service received. Customers have also noted that Acas either solved or made progress towards a settlement in $90 \%$ of the cases. A total of $87 \%$ of customers would recommend the service or use it again and. The recent Acas evidence shows that both employers and trade unions rated conciliators the highest (a score of 5 out of 5) on how well they listened to them, remained impartial, established rapport with them and presented issues in neutral language. Furthermore, a total of $84 \%$ of the employers and $90 \%$ of the trade union participants in the recent survey strongly agreed that their conciliator was trustworthy (Booth et al., 2016).

The economic arguments underlying collective conciliation and mediation schemes provided by Acas are quite strong. Research suggests that collective conciliation has net economic benefits of $£ 147.8$ million with only $£ 1.8$ million of net cost. As such, collective conciliation is the second most effective Acas service in terms of benefit/cost ratio, only preceded by E-learning (Urwin \& Gould, 2016). The recent data also suggests that Acas' intervention in collective conflicts in relation to 14 key collective disputes across 2013-2014 and 2014-2015, respectively, led to a net economic impact in terms of loss avoided of $£ 255.3$ million (Urwin \& Gould, 2016).

Overall, the conciliation service was suggested to have sped up the dispute resolution, it managed to bring both sides closer together and helped avoid industrial action. Nevertheless, organizations, particularly SMEs where the uptake of collective conciliation is lower, may need more evidence of the benefits of collective conciliation and mediation in order to use it more frequently for collective conflict resolution.

\section{Evaluation by Stakeholders of the Effectiveness of the Mediation}

In line with previous research, our findings suggest that Acas has been achieving a high level of success in settling collective conflicts. These findings were corroborated in our interviews whereby our trade union participants suggested that Acas was a trustworthy and impartial "partner" in helping them negotiate and solve collective conflicts with employers. Furthermore, policy makers also reported an extremely high value of Acas' service for the economy. Specifically, according to Acas' chief conciliator, 'the value of our service is phenomenal... research suggests that for every pound Acas spends on the service the economy saves $£ 80$ '.

\subsection{Conclusions}

Our recommendations from the experts' point of view can best be summarized as follows:

1. Collective conciliation by Acas is widely valued. This relative decline in demand reflects changes to the institutional environment in which it operates, most notably the decline in trade union membership levels. Acas as an institution continues to 
draw on the expertise of its senior advisors as they offer both collective dispute resolution and dispute prevention services via in-depth work inside organizations and through the provision of training.

2. It is important that Acas continue with the internal monitoring and evaluation of its performance in terms of collective conciliation. It is important that Acas maximizes its service provision with respect to collective dispute resolution, so that it continues to operate as the premier conciliation service in Great Britain. For example, for Acas it is key to increase its penetration rates in intervening in collective conflicts and proactively looking to get involved in collective disputes.

3. It is key that Acas continues to work with parties on recognition agreements. This would facilitate early involvement of Acas in workplaces and enable relationship building at regional levels.

4. Policy makers and providers could do more work if mediation is something that is seen useful for building effective workplaces. In this respect, it would be important to explore more what sort of interventions for collective conflict resolution could be done.

5. In relation to the previous point, it has been noted that we need a greater understanding of what we mean by different kinds of interventions. Our findings suggested there was a lack of clarity in terms of how information, consultation, negotiation and problem solving differ, particularly from the employers' perspective. Acas and other service providers could offer training to employers' and employees' representatives to help understand the key terms and possible interventions better.

6. Finally, it has been suggested that hardly any practicing mediator in the UK would accept the Acas' definition of conciliation and mediation in collective bargaining process. Most people practice facilitative mediation and see conciliation as such. As one mediator reflected 'this issue of terminology relates to the lack of understanding about what the role of mediator in the facilitative approach can actually mean...mediation is often seen as a last resort, but it should not be viewed as such... it is not a last resort, it is something that you look at earlier in the process.'

Giving the legislative changes in the balloting process in the trade Union Act of 2016, there will be more demand in trade disputes for collective conciliation. Therefore, it is important that it remains a free service in order to maintain harmony in employment relations and efficient dispute resolution.

Even though Britain's voluntarist approach to employment relations is somewhat atypical compared to its European counterparts_-given the preferences of key stakeholders, as well as the impartiality of Acas, the current dispute resolution procedures are working well. Therefore, a more regulated approach to dispute resolution is, in the current employment relations climate, not called for.

\footnotetext{
Aknowledgements We would like to offer thanks for the enormous help and support offered by several members of Acas in preparation of this chapter. A special thank you to David Prince, Gill Dix, Sarah Podro \& Frank Blair. Finally, we would like to thank all our participants who gave up valuable time and shared their expert opinions and experiences with us.
} 


\section{References}

ACAS. (2013). Mediation: An approach to resolving workplace issues. London: ACAS.

Adam, D., Purcell, J., \& Hall, M. (2014). Joint consultative committees under the information and consultation regulations: WERS analysis. London: ACAS.

Arrowsmith, J. (2008). Strike over pensions hits oil and gas production. European Observatory of Working Life. Retrieved from https://www.eurofound.europa.eu/observatories/eurwork/articles/ strike-over-pensions-hits-oil-and-gas-production.

Balakrishnan, A. (2008, April 25). Q\&A: The Grangemouth dispute. The Guardian. Retrieved from https://www.theguardian.com/business/2008/apr/25/oil.energy.

BBC (2013, October 21). Grangemouth dispute: Union members reject Ineos offer. BBC. http:// www.bbc.co.uk/news/uk-scotland-24603346.

BBC (2014, February 4). Grangemouth Unite convener Mark Lyon sacked. BBC. Retrieved from http://www.bbc.co.uk/news/uk-scotland-tayside-central-26039630.

Bollen, K., Euwema, M., \& Munduate, L. (2016). Advancing workplace mediation through integration of theory and practice. London: Springer International Publishing.

Bond, C. (2011). Trade union officers' preferences and attitudes towards dispute resolution: A qualitative follow-up study with non-users of Acas collective conciliation. London: ACAS.

Booth, C., Clemence, M., \& Gariban, S. (2016). ACAS collective conciliation evaluation 2016. London: ACAS.

Certification Officer (2016). Annual report of the certification officer: 2015-2016. Retrieved from https://www.gov.uk/government/uploads/system/uploads/attachment_data/file/537915/ CO_Report_15-16.pdf.

Corby, S. (2015). Arbitration in collective disputes: A useful tool in the toolbox. London: ACAS.

Dawe, A., \& Neathey, F. (2008). Acas conciliation in collective employment disputes. London: ACAS.

Dix, G., \& Oxenbridge, S. (2004). Coming to the table: The role of ACAS in collective disputes and improving workplace relationships. London: ACAS.

Dix, G., Forth, J. A., \& Sisson, K. (2008). Conflict at work: The pattern of disputes in Britain since 1980. London: ACAS.

Dix, G., \& Barber, S. B. (2015). The changing face of work: Insights from Acas. Employee Relations, 37, 670-682.

Gibbons, M. (2007). A review of employment dispute resolution in Great Britain. London: DTI.

Hall, M., Hutchinson, S., Purcell, J., Terry, M., \& Parker, J. (2011). Promoting effective consultation? Assessing the impact of the ICE regulations. British Journal of Industrial Relations, 51(2), 355-381.

Heery, E., \& Nash, D. (2011). Trade union officers and collective conciliation: A secondary analysis. London: ACAS.

Latrielle, P. (2011). Mediation: A thematic review of the Acas/CIPD evidence. London: ACAS.

Lyon, H. M. (2017). The battle of Grangemouth: A worker's story. Chadwell Heath: Lawrence \& Wishart Ltd.

McAlpine, R. (2013) What's really happening at Grangemouth and what it tells us. https://www. opendemocracy.net/ourkingdom/robin-mcalpine/whats-really-happening-at-grangemouth-andwhat-it-tells-us (retrieved March 2018).

Molloy, D., Legard, R., \& Lewis, J. (2003). Resolving collective disputes at work: User perspectives of Acas collective conciliation services. London: ACAS.

Office of National Statistics (ONS). (2018). UK labour market: March 2018. Retrieved from https:// www.ons.gov.uk/employmentandlabourmarket/peopleinwork/employmentandemployeetypes/ bulletins/uklabourmarket/march2018.

Peev, G. \& Allen, V. (2013, October 28). Unite boss whose labour activities triggered shock closure of rangemouth QUITS just days after plant was saved when union caved in. Daily Mail. Retrieved from http://www.dailymail.co.uk/news/article-2478460/Unite-boss-Stevie-Deans-quits-Labouractivities-triggered-shock-closure-Grangemouth.html\#ixzz5B4Izzvpm. 
Podro, S., \& Suff, R. (2005). Making more of alternative dispute resolution. London: ACAS.

Podro, S., \& Suff, R. (2009). The alchemy of dispute resolution-The role of collective conciliation. ACAS.

Renaudon, C. (2017, September 21). Abolition of tribunal fees: Next steps for employers. Personnel Today. Retrieved from https://www.personneltoday.com/hr/abolition-tribunal-fees-nextsteps-employers/.

Ruhemann, C. (2010). Trade union negotiating officials' use and non-use of Acas conciliation in industrial disputes. London: ACAS.

Saundry, R., Bennett, A. J. W., \& Wibberley, G. (2013). Workplace mediation: The participant experience. London: ACAS.

Seymour, R. (2013, November 2013) How Ineos humiliated Unite in Grangemouth. The Guardian. Retrieved from https://www.theguardian.com/commentisfree/2013/nov/09/ineos-unite-uniongrangemouth-oil-refinery.

Urwin, P., \& Gould, M. (2016). Estimating the economic impact of ACAS services. London: ACAS.

Van Wanrooy, B., Bewley, H., Bryson, A., Forth, J., Freeth, S., Stokes, L., et al. (2013). Employment relations in the shadow of recession: Findings from the 2011 workplace employment relations survey. Hampshire: Palgrave Macmillan.

Open Access This chapter is licensed under the terms of the Creative Commons Attribution 4.0 International License (http://creativecommons.org/licenses/by/4.0/), which permits use, sharing, adaptation, distribution and reproduction in any medium or format, as long as you give appropriate credit to the original author(s) and the source, provide a link to the Creative Commons license and indicate if changes were made.

The images or other third party material in this chapter are included in the chapter's Creative Commons license, unless indicated otherwise in a credit line to the material. If material is not included in the chapter's Creative Commons license and your intended use is not permitted by statutory regulation or exceeds the permitted use, you will need to obtain permission directly from the copyright holder. 